\title{
PROSODY DRIVES STRUCTURE: THE CASE OF COMPOUNDS IN AKAN
}

\author{
Charles Marfo \\ Department of Modern Languages, \\ Kwame Nkrumah University of Science and Technology, Kumasi, Ghana \\ cmarfo@gmail.com / cofosu-marfo.socs@knust.edu.gh
}

\begin{abstract}
This paper discusses compound constructions in Akan, which are mostly nouns. Compounding is generally explained as a morphosyntactic word-formation process and the resulting compound word is commonly described as a "new" linguistic unit (Haspelmath, 2002; Marfo, 2009). The paper focuses on Noun-Noun (N-N) and Noun-Adjective (N-Adj) compounds in Akan and particularly contends that, for N-N and $\mathrm{N}$-Adj compounds to be realized in Akan, the compound members should map into one prosodic phrase. It is also suggested that the same mapping should be the case if there could be proper or consistent realization of some phonological changes that occur in the compound. In this direction, the paper explains that the syntactic structure of the compound (i.e., the noun phrase (NP)), does not solely ensure the domain of the Akan compound nor the domain properties that trigger the rules that apply in it, but phonological information as well; thus, prosodic constraints are observed. Furthermore, the structure of the Akan compound is illuminated in terms of Attribute-Value Matrix (e.g., Butt \& King, 1998). The paper reiterates in conclusion that compounds in Akan and rules that apply in them are better accounted for through dictates of the prosodic structure.
\end{abstract}

Keywords: Compounding, phonology-syntax interface, prosody, noun phrase

\section{Introduction}

This paper takes a look at compound constructions in Akan. Compounding is generally discussed as a morphosyntactic word-formation process (e.g., Lieber, 1980). The resulting compound word is often described as a "new" linguistic unit (word/lexeme) that is made out of two or more independent words (Bybee, 1985; Fabb, 1998; Haspelmath, 2002). Anderson (1985), in particular, describes a compound word as "word formation based on the combination of two or more members of (potentially) lexical classes" (p. 40). Considering the involvement of individual lexemes (Haspelmath, 2002, p. 85), a compound could be regarded as involving a quasi-syntactic structure.

Compounding is one way by which Akan increases its stock of vocabulary and it is done through the association of words from the same category or different 
categories. In Akan, Bresnan (1990) and Dolphyne (1988) identify six two-word compound forms: Noun-Noun, Noun-Adjective, Verb-Verb, Verb-Noun, AdjectiveNoun, and Noun-Verb. This paper focuses on Noun-Noun and Noun-Adjective (respectively notated as $\mathrm{N}-\mathrm{N}$ and $\mathrm{N}$-Adj) compounds because they are more productive in Akan. As noted by Marfo (2009), also of significance is the fact that the non-noun compound members in the Verb-Verb, Verb-Noun, Adjective-Noun, and Noun-Verb compounds are nominalised before they are compounded. In other words, they become nouns through inflection for nominal prefixe(s) before the compounding. So, they end up as N-N.

This paper contends that constituents/words involved in the realisation of a compound in Akan should map into one prosodic phrase, specifically the phonological phrase $(\phi)$. Otherwise, there could be no compounding. It will be shown that whether or not separate words could map into one $\phi$ and to constitute a compound is dependent on the tonal structure of the first constituent. In view of this fact, the immediate claim is that the categorial structure (c-structure) of the compound members - the noun phrase (NP) - does not solely ensure the prosodic domain for an Akan compound and its internal rules.

The rest of the paper is organised as follows. The structure of N-N and N-Adj compounds is presented in the immediately following section. In the section on Some rules in Akan compounds, the phonological processes or rules that occur in $\mathrm{N}$ $\mathrm{N}$ and $\mathrm{N}$-Adj compounds are discussed. The section on Domain of the Akan compound and its internal rules explains the phonological phrase $(\phi)$ and its properties and other conditions sensitise various rules that apply in compounds. In the section on Domain of compounds in Attribute-Value Matrix, individual domain structures of two forms of compounds and boundary tones that set them apart are presented in terms of Attribute-Value Matrix (AVM). The final section concludes the paper with the reiteration that the compound in Akan and the rules that apply in it are better accounted for with prosodic considerations.

\section{Structure of Akan Compounds}

In N-N compounds of Akan, the first compound member (N1) modifies the second one (N2). The same modification takes place in N-Adj compounds, but in the opposite representation; i.e., the adjective occurs at post-position in connection with the noun and performs its function of modifying the noun. $\mathrm{N}-\mathrm{N}$ and $\mathrm{N}$-Adj compounds are respectively exemplified in (1) and (2).
$\mathrm{N} 1+\mathrm{N} 2$
a. ǹnùá + غ̀dáń "woods, a house"
b. ǹkátéé + ǹkwáń "groundnut, soup"
c. òdwáń + òníní "a sheep, a male"
d. àhéné + èfié

\begin{tabular}{|c|c|}
\hline Compound & \\
\hline " ǹnùàdáń & "wooden house" \\
\hline » ǹkàtèǹkwáń & $\begin{array}{l}\text { "groundnut } \\
\text { soup" }\end{array}$ \\
\hline " òdwàníní & "ram" \\
\hline » àhìmfíé & "palace" \\
\hline
\end{tabular}


(2)

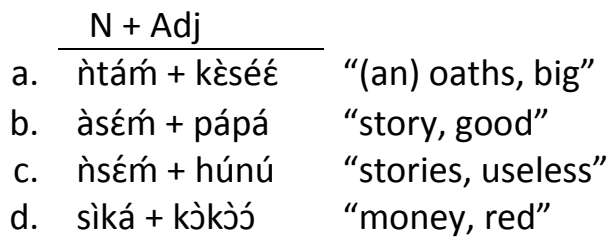

\begin{tabular}{|c|c|}
\hline Compound & \\
\hline » ǹtàǹké!séé & "(a) great oaths" \\
\hline "àsèm̀ná(pá) & "good news" \\
\hline » ǹsèǹhúnú & “nonsense" \\
\hline " sikkàkókj̀j́ & “gold" \\
\hline
\end{tabular}

Typically, an Akan compound is neither lexicalised in meaning nor in its English translation. Where lexicalisation seems to be the case, it is often coincidental, as in ( $1 c \& d)$ and ( $2 c \& d)$. Furthermore, it is important to observe that the $\mathrm{N}+\mathrm{N}$ compounds in Akan are normally realised as single lexical units. The $\mathrm{N}+\mathrm{Adj}$ ones, on the other hand, can also be realised as single lexical units or as separate units in certain instances. Generally, where a compound is described as lexicalised, the individual meanings of the compound members may not be explicitly evident in the meaning of the composite word. Consequently, the modification effect may be hidden. However, in satisfaction of the semantic principle of compositionality (Gamut, 1991; Montague, 1974), the individual meanings of the compound members are not totally lost. The compositionality principle requires the realisation of the basic meanings of individual units in the composite expression of a derived unit. Conversely, in non-lexicalised compounds, the semantic contents of the compound members are immediately realised in the composite meaning, as in (1a \& b) and ( $2 a \& b)$.

The Akan compound could be described as a syntactic word on the basis of the Lexical Integrity Principle (LIP) (e.g., Bresnan \& Mchombo, 1995) that constrains the c-structure. LIP suggests that only morphologically complete words may be leaves of c-structure. Thus, a compound would correspond to one and only one cstructure node, so that the internal structure of it cannot be accessed by the syntax. But, we observe that a compound does not correspond to a phonological word $(\omega)$ in the prosodic structure ( $p$-structure). That is, we consider a compound in Akan as a word that is contained in a prosodic constituent that is larger or higher than a prosodic word $(\omega)$. In addition and more importantly, the word order of compound members is a reflection of their order in the syntax. Thus, constituent headedness in the light of the X-bar theory of phrase structure (Jackendoff, 1977) is maintained in the resulting compounds, particularly in the N-Adj compounds. Hence, the majority of $\mathrm{N}-\mathrm{N}$ and $\mathrm{N}$-Adj compounds in Akan could be described as endocentric - i.e., they are headed like syntactic phrases. It is suggested that, like a syntactic head, "the head [of a compound] represents the core meaning of the composite constituent, and it is of the same word class [as the resulting compound]" (Fabb, 1998, p. 67). Based on the core meaning and the same class criteria, observe in (3) that N2 becomes the head of $\mathrm{N}-\mathrm{N}$ compounds, while $\mathrm{N} 1$ constitutes the head of N-Adj compounds in Akan. 
(3)

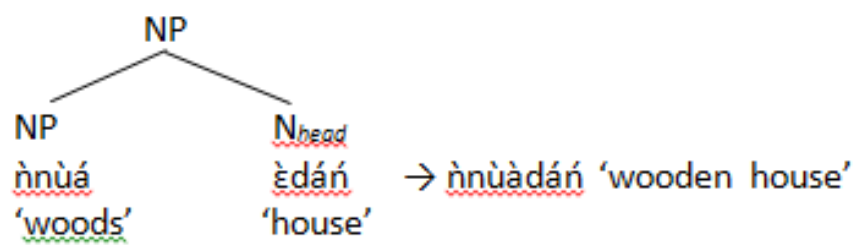

b.

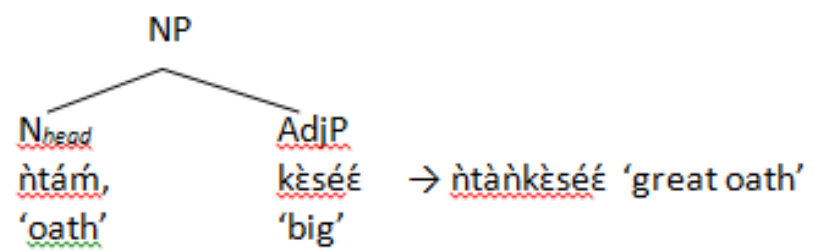

Observe in (3) that $\mathrm{N}-\mathrm{N}$ compounds take after the left-branching configuration of the noun phrase (NP) of a language like English - [NP NP N]. The NAdj cases, on the other hand, closely relate to the NP in Akan, [NP N AdjP]. Specifically, an adjective always comes after the noun (head) it modifies in Akan and this phrase structure is maintained in the compound.

As also shown in (4) below, a look at the Akan compound through the morphological analyzer- "a finite state machine which encodes ... rules of compounding" (Butt, King, Niño, \& Segond, 1999, p. 92) - clarifies that a compound expresses more information than what its compound members individually express. In other words, the functional structures (f-structures) in (4a \& b) explain that the head nouns (i.e., N2 in N-N and N1 in N-Adj) carry the predicate (PRED) attribute of the compounds. And, becoming part of the PRED, the adjuncts then attribute properties to the head.

(4)

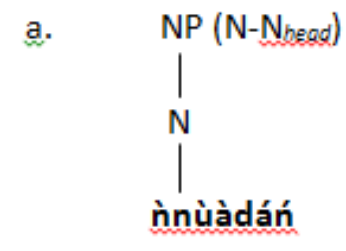

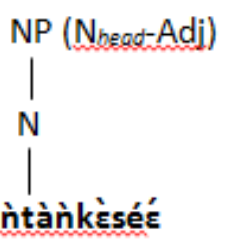

b.

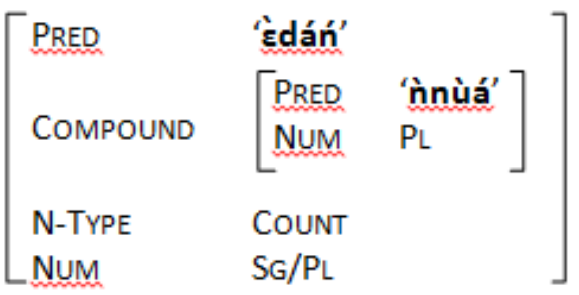

$\left[\begin{array}{lll}\text { PRED } & \text { 'ǹtám' } & \\ \text { COMPOUND } & \text { [PRED } & \text { 'kèsés'] } \\ \text { N-TYPE } & \text { COUNT } & \\ \text { NUM } & \text { SG } & \end{array}\right]$

In (4a) in particular, observe that the adjunct is a plural noun (i.e., [NUM PL]), but the derived compound in Akan is not specified for number. As will become evident, information like this render compounds in Akan complex. Prosodic analysis of grammatical information in them, therefore, becomes desirable. N-TYPE in (4) also means "noun type". 


\section{Some Rules in Akan Compounds}

Dolphyne (1988) identifies six phonological changes/occurrences in Akan compound constructions. These are vowel harmony, homorganic nasal assimilation, nasalisation of voiced plosives, loss of final vowel (or syllable), loss of vowel or nasal prefix, and changes in the basic tones of stems. We focus on changes in the basic tones of stems, loss of final vowel or syllable, and loss of a prefix (i.e., onsetless or single-segment initial syllable) in this paper and discuss them in terms of the phonology-syntax interface.

\section{Changes in the Basic Tones in Compound Members}

Dolphyne (1988) notes two alternative surface tone realisations in the first compound member (N1) in the Akan compound: i) N1 is said on low (L) tone in some compounds the lexical tone pattern of N1 is maintained in some others. In terms of rule application, I suggest that where $\mathrm{N} 1$ is said on $\mathrm{L}$ tone, it is due to rule application referred to as H-Deletion following Marfo $(2004,2009)$. That is, as schematised in (5), with $\mathrm{H}$-Deletion, $\mathrm{N} 1$ is rid of its lexical $\mathrm{H}$ tone(s) and then pronounced $\mathrm{L}$ by default. This is exemplified in N-N and N-Adj compounds in (6) and (7) respectively. We note however that $\mathrm{H}$-Deletion is essentially optional in the $\mathrm{N}$ Adj compounds.

(5) The H-Deletion rule

$$
\left[\ldots \sigma^{\mathrm{H}} \ldots\right]_{\mathrm{N} 1} \rightarrow\left[\ldots \sigma^{\mathrm{L}} \ldots\right]_{\mathrm{N} 1} \quad /\left[\mathrm{NP}-[\ldots \sigma \ldots]_{\mathrm{N} 2 / \mathrm{Adj}}\right]_{\text {Compound }}
$$
a. nyàmé + àséḿ "god, story"

\begin{tabular}{|c|c|}
\hline Compound & \\
\hline " nyàmèsćḿ & “scriptures" \\
\hline " àtùdúró & "gun powder" \\
\hline " àbòsòmìfié & "shrine" \\
\hline » àhòhòdáń & "guesthouse" \\
\hline
\end{tabular}
b. àtùó + àdúró "guns, medicine"
c. àbó!sóm + èfié "idols, house"
d. àhó!hój́ + c̀dáń "guests, house"

(7)

$$
\begin{aligned}
& \text { " compoùsàtéńtéń "a talkative" } \\
& \text { " ǹsàfúfúó "palm-wine" } \\
& \text { " àdwùmàdéń "difficult task" } \\
& \text { " sikàkj̀kòj "gold" }
\end{aligned}
$$

\section{Loss of Initial Syllable and Final Vowel or Syllable}

As noted earlier, Dolphyne (1988) also notes two segmental alterations in Akan compounds. These are loss of prefix in N2 and loss of final vowel or syllable in N1. Specifically, let us refer to them as prefix elision and vocalic sequence shortening respectively and they could be verified from the N-N data in (8) and N-Adj data in (9). 
(8)

\begin{tabular}{|c|c|c|c|c|}
\hline & $\mathrm{N}+\mathrm{N}$ & & Compound & \\
\hline & ǹnùá + Èdáń & "woods, house" & » ǹnùàdáń & "wooden house" \\
\hline & ònùá + j̀dó & "sibling, love" & » ònùàdó & "brotherly love" \\
\hline & àtúó + àdúró & $\begin{array}{l}\text { "guns, } \\
\text { medicine" }\end{array}$ & » àtùdúró & "gun powder" \\
\hline & & "chiefs, house" & " àhìr & "palace" \\
\hline & dàdéé + દ̀sćń & "iron, cookware" & » dàdèsćń & "iron cookware" \\
\hline
\end{tabular}

(9)

\begin{tabular}{|c|c|c|c|c|}
\hline & $\mathrm{N}+\operatorname{Adj}$ & & Compound & \\
\hline & ǹkwàǹtá + દ̀náń & "junction, four" & » ǹkwàǹtànáń & "crossroad" \\
\hline & àfidié + mónó & "machine, new" & » àfidìmónó & "new machine" \\
\hline & òkúnú + pá & $\begin{array}{l}\text { "husband, } \\
\text { good" }\end{array}$ & » òkùǹpá(pá) & "good husban \\
\hline & íré t & "head, bad" & » ètìbòné & "bad luck" \\
\hline & j̀yéré + fó!fóró & "wife, new" & » àyèfóró & "newly wed" \\
\hline
\end{tabular}

These two occurrences have to do with the kind of vocalic sequence that is allowed at the boundary of compound members. Observe from (8) and (9a) that a vowel in N2 is elided in the resulting compound. That is loss of prefix referred to here as prefix elision. Prefix elision is schematised in (10a).

a. Prefix elision

$$
\left[{ }_{\mathrm{N} 2} \sigma_{\text {Prefix }}-\sigma_{\ldots .}\right] \quad \rightarrow\left[{ }_{\mathrm{N} 2}-\sigma \ldots\right] \quad /\left[\left[_{\mathrm{N} 1} \sigma \ldots\right] \ldots\right]_{\text {Compound }}
$$

b. Vocalic sequence shortening

$$
\left[{ }_{\mathrm{N} 1} \ldots v v / N v\right] \quad \rightarrow\left[{ }_{\mathrm{N} 1} \ldots v / N\right] \quad /\left[{ }_{\mathrm{N} 2} \ldots[\sigma \ldots]\right]_{\text {Compound }}
$$

Also schematised in (10b) is vocalic sequence shortening. That is, it could be observed in (8) and (9), a final vocalic sequence (i.e., either vowel-vowel or liquid/nasal-vowel) in N1 is simplified in a compound. Specifically, observe that where the vocalic sequence is "vowel-vowel" (vv) or "nasal-vowel" (Nv), vocalic sequence shortening is realised by a simple deletion of the last vowel, as could be seen in ( $8 c \& d)$ and in ( $9 b \& c)$. In a vocalic sequence of "vowel-vowel" $(v v)$ however, where the succeeding vowel is /a/, vocalic sequence shortening is blocked as can be seen in ( $8 a \& b)$. In the case of "liquid-vowel" sequence, the whole syllable is deleted as shown in (9d \& e). Indeed, most words with final "liquid-vowel" sequence, [re], could be said without it in Asante-Twi. Thus, it could be assumed that the short forms rather enter into the compounding, hence the exclusion of "liquidvowel" sequence in the schematisation of vocalic sequence shortening.

\section{Domain of the Akan Compound and Its Internal Rules}

As noted earlier, at a glance, it is obvious that NP is the domain of N-N and N-Adj compounds and, in particular, the rules we have identified as applying in them. However, considering the position that the involvement of syntax in phonological 
rule applications is only remote, we observe in this section that the $\phi$ (from the prosodic structure) is rather the required domain. And, more importantly, it is properties of the $\phi$ that the rules (particularly H-Deletion) refer to for application. The suggestion therefore is that a compound in Akan is attained where the NPinternal constituents (i.e., $\mathrm{N}-\mathrm{N}$ or $\mathrm{N}$-Adj) are mapped into one $\phi$. Considering the Strict Layer Hypothesis (SLH) (Selkirk, 1984, 1986,) of the prosodic hierarchy, which requires each prosodic domain to contain only pieces of immediate lower domains, each constituent in the NP-mapped $\phi$ is a prosodic word $(\omega)$, as shown in (11a \& b) for N-N and N-Adj compounds respectively.

(11)

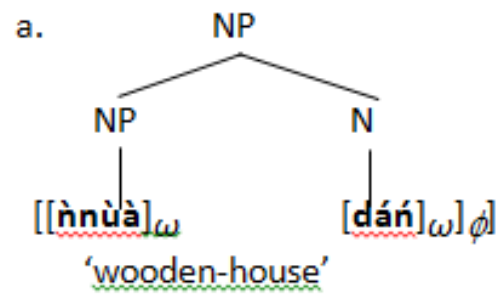

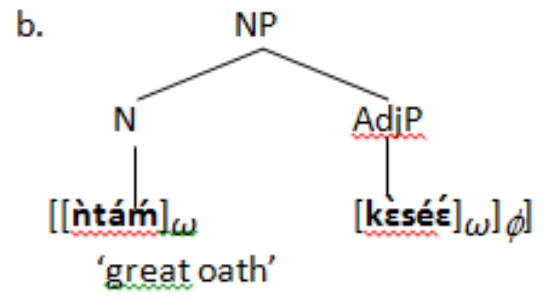

Linguists differ on the number of levels that constitute the prosodic hierarchy. We observe one of six levels in a descending order as Phonological utterance $(U)$, Intonational phrase $(I)$, Phonological phrase $(\phi)$, Phonological word $(\omega)$, Foot $(\Sigma)$ and Syllable $(\sigma)$.

Now, revisiting the H-Deletion rule (as observed earlier), we suggest that it only applies where compound members are immediately contained in the $\phi$; i.e. $[[\omega][\omega]] \phi$ and as shown in (11). Presently, however, as could also be seen in (11), it is undeniable that NP as the basic syntactic structure is also adequate for the N-N and $\mathrm{N}$-Adj compound constructions and for the application of $\mathrm{H}$-Deletion. Thus, the direct-syntax approach (e.g., Kaisse, 1985; Odden, 1990) is applicable. In this section, we observe other issues in the compound constructions that render direct-syntax analysis (of phrasal rules) inadequate and rather motivate prosodic analysis. The direct-syntax approach basically advances the position that, in the phonology-syntax interface analysis of phrasal rules, domains that are directly realised in the morphosyntactic structure (e.g., those resulting from c-command relations) predict the application of the rules that come to bear in various constructions.

\section{Tonal Structure of $\mathrm{N} 1$ and $\mathrm{H}$-Deletion}

It has been noted that $\mathrm{H}$-Deletion consistently applies in compounds irrespective of the segmental representation of the compound members. However, a scrutiny of a few other $\mathrm{N}-\mathrm{N}$ compounds (as against those we have seen so far) reveals that $\mathrm{H}$ Deletion reacts to the tonal structure of N1. Specifically, the tonal structure of N1 must be $\mathrm{L}$-initial and $\mathrm{H}$-final to allow the application of $\mathrm{H}$-Deletion in it. Otherwise, as could be witnessed in the date in (12), H-Deletion does not apply. 
(12)
$\mathrm{N}+\mathrm{N}$
a. lórè + Èkwáń "lorry, way"
b. ádàsà + mmmá "people, children"
c. táyà + àtój "catapult, shooting"
d. kòóbì + ǹkwáń
"salted-fish, soup"
e. òwúrà + kwààkú
"lord, personal
name"

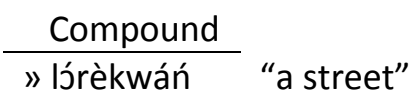


$\mathrm{N}$-Adj compounds that involve separate units. So, the lexical tones of the N1s could also be maintained.

(15) Irrelevance of Word-Edge in N-Adj compound
$\mathrm{N}+$ Adj
a. lórè + kétéwá "lorry, small"
" lòrèkétéwá "a small car"
b. òwúrà + pápá "lord, good"
c. táyà + kèséé "catapult, big"
" òwùràpá(pá) "a good master"
d. dúkù + téńtéń "scarf, long"
» tàyàkèséć "a big catapult"
e. bótó + fó!fóró "a sack, new"
» dùkùtéńtéń "a long scarf"
» bj̀tว̀fó!fóró "a new sack"

\section{Exceptions and the Need for $p$-Structure}

From the discussions so far, one expects that whenever Word-Edge is met in N1 of $\mathrm{N}-\mathrm{N}$ compounds, H-Deletion should take place. This is however not the case. As a characteristic of many phonological rules and as noted by Anyidoho (1990) and Dolphyne (1988), there are a few N-N compounds within which H-Deletion does not apply, even though the N1s satisfy Word-Edge. Some of these compounds are shown in (16).
$\mathrm{N}+\mathrm{N}$
a. àkókó + òníní "chicken, male"
Compound
b. غ̇kón + غ̀pó "neck, knot"
" àkókóníní "cockerel"
c. غ̇sóró + àbóá "sky, animal"
" غ̇kóḿnó "goiter"
d. ètíré + ǹnwíl "head, hair"
"à/Èsóróbóá "e.g. bat"
e. yàré + m̀pá "sickness, a bed"
» ètí!nwíl "hair"
f. àsóré + Èdáń "worship, building"
" yàré!pá "sick bed"
" àsórédán "church"

In terms of direct-syntax analysis, the data in (16) would have to be regarded as exceptions to H-Deletion. This is because N1 and N2 are still contained in NP (just like with those within which the rule consistently applies). Also, each N1 meets the immediate constraint of Word-Edge, failure of which would have explained the nonapplication of H-Deletion. With the present prosodic account, however, it is conveniently explained that these compounds only constitute a case where the desired prosodic domain order to trigger $\mathrm{H}$-Deletion is not attained in the $\mathrm{p}$ structure of these compounds. In other words, the basic syntactic structure of NP is prosodized into $\phi$ differently. I account for the different domain structure in (16), as follows.

In Akan, tone is not assigned post-lexically to infer accentual structures, as in Kimatuumbi (Odden, 1987) for instance. Therefore, we assume that an assigned tone or tonal structure at the lexical level is also inherently accentuated (Marfo, 2004). However, we do not expect maintenance of this lexical but inherently accentuated tonal structure in a post-lexical environment if a particular tone rule has to apply. Thus, in compounds, the tonal structure of $\mathrm{N} 1$ must yield to H-Deletion once Word-Edge is met. In (16) however, N1 fails to yield to H-Deletion and this is due to the attainment of a phonological factor, tonal prominence, in the N1s. Tonal 
prominence enforces maintenance of the lexical tone structure (and, for that matter, the inherent accentuation) in N1s even in the post-lexical environment of compounds. Tonal prominence follows from the tonal prominence scale (de Lacy, 2002), which proposes that higher tone is more prominent than lower tone. It follows then that, in a two-tone language like Akan, $\mathrm{H}$ tone is prominent than $\mathrm{L}$ tone (i.e., $\mathrm{H}>\mathrm{L}$ ). This is captured by the Compositional Mapping Theory (CMT) (Marfo, 2005) as follows: a tonally prominent lexical complement of a branching NP primarily maps into one $\phi$.

Now, from the point of view of CMT, it is claimed here that the nonapplication of $\mathrm{H}$-Deletion in (16) is due to primary mapping of the complement (N1) into a separate $\phi$ by the mandate of tonal prominence, as shown in (17). But, as (17) also shows, compounding is still possible because of a subcategorisation frame (set up by the tonally prominent complement) that ensures $\phi$-domain rephrasing with N2.

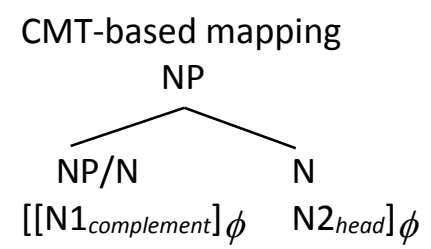

The frame is inspired by Zec and Inkelas' (1990) proposal in their explanation of issues relating to presentational particle, $f a$, in Hausa. In the same work, a $\omega$-domain subcategorisation frame for clitics in Serbo-Croatianis is also proposed. Here, the frame is necessary because N2 cannot be mapped into a separate $\phi$ (in the singular form).

Observe in (17) that the primary $\phi$ containing N1 institutes a right-edge $\phi$ boundary between it and $\mathrm{N} 2$ and, considering the fact that H-Deletion is only prompted within a primary $\phi$ of two $\omega s$, we note that it is this internal $\phi$-boundary that desensitises its application in the compounds in (16), repeated in (18) below for ease of reference. Within the p-structure of the grammar therefore, both the realisation of a compound and the non-application of $\mathrm{H}$-Deletion are adequately accounted for. Also observe in (18) that vocalic sequence shortening and prefix elision apply. Unlike H-Deletion, however, they are not restricted to apply in a primary $\phi$; they apply when the compound members are contained in a $\phi$.

(18) Exception to H-Deletion

\begin{tabular}{|c|c|c|c|c|}
\hline & & & Compound & \\
\hline & [[àkó & “chicken, male" & " àkókóníní & \\
\hline & & "the neck, I & ॥ غ̇kó & \\
\hline ( & [[èsór & “sky, a & róbóá & . bat" \\
\hline & [[ètí & "the I & » èt & \\
\hline & & "sic & "yà & bed" \\
\hline & [[àsóré] $\phi$ c̀dáń] $\phi$ & "worship, building" & " àsóré!dáń & "church" \\
\hline
\end{tabular}




\section{Domain Recursion and Boundary Assimilation}

The subcategorisation frame observed in (17) exhibits a $\phi$-domain recursion - i.e. [[ ] $\phi \ldots] \phi-$ internal boundary of which blocks $\mathrm{H}$-Deletion from applying as exemplified in (18). Alternatively however, the internal boundary sets off a tone sandhi. Noted as the boundary assimilation rule (B-A) following Marfo (2005) and as schematised in (19) below, in its application, the prefix of a succeeding compound member (N2) is assimilated by the final tone of the preceding one (N1). So, in the N-N compounds in (18) above, we observe that B-A is initiated by the final $\mathrm{H}$ tone of $\mathrm{N} 1$ and realises in the prefix of N2. Domain-wise, note that it is the internal $\phi$-boundary in the recursive structure that triggers $\mathrm{B}-\mathrm{A}, \phi$-domain juncture rule. $\mathrm{B}-\mathrm{A}$, therefore, could not have applied without the internal $\phi$-boundary.

$$
\begin{aligned}
& \text { The boundary assimilation rule } \\
& \left.\left[{ }_{\mathrm{N} 2} \sigma_{[\text {Prefix }]}^{\mathrm{L}}-\sigma\right]_{\omega} \rightarrow\left[\sigma_{[\text {Prefix }]}^{\mathrm{H}}-\sigma\right]_{\omega} \quad /\left[{ }_{\mathrm{N} 1} \ldots \sigma^{\mathrm{H}}\right]_{\phi}-\right]_{\phi}
\end{aligned}
$$

Since in a compound the prefix in N2 is deleted (recall prefix elision), the effect of $B-A$ is not obvious if the lexical $L$ tone of the prefix is deleted along with it. Such is the case in $(18 a-c)$. On the other hand, where the lexical $L$ tone is not deleted along, B-A is realised by the dislodging of this lexical tone by the "assimilating" $H$ in N1. As a result, as also shown in in (18d-e), the dislodged L tone causes pitch reduction in the stem-initial $\mathrm{H}$ tone, hence the downstepping of the stem-initial $\mathrm{H}$ of $\mathrm{N} 2$.

\section{Domain of Compounds in Attribute-Value Matrix}

In order to relate phonological information to the parallel structures of LFG, in particular, the c-structure, Butt and King (1998) encode the p-structure in terms of an attribute-value matrix (AVM). In the encoding, Butt and King explain that the AVM of the $p$-structure is projected from the hierarchical (pseudo-tree) structure of the $p$-structure, not from the c-structure. The reason, perhaps, is that the $p$ structure involves more than the c-structural information. Butt and King also explain that the AVM of the $p$-structure contains attributes such as phonological form ( $P$ FORM), prosodic domain (DOM), tone, etc. (see (20)). In this sense, as they put it, the attributes in the $p$-structure are generally prosodic in nature. Through the enforcement of projection precedence, they further contend that, for this AVM to be useful in all phonological processes, the linear order of the phonological string should be maintained in the AVM. Thus, the AVM of the $p$-structure is unlike that of the f-structure, which is not ordered. Butt and King do not particularly explain projection precedence, but it is related to precedence relation between syntactic nodes. For instance, between nodes $A$ and $B$, precedence is explained in the syntax as "node $A$ precedes node $B$ if and only if $B$ is to the right of $A$ and neither $A$ nor $B$ dominates the other".

Besides the prosodic mappings, in this work, AVM of the p-structure is particularly made use of to give explicit representation of lexical and phrasal tone structure in the Akan compound. As could be observed in (20), the AVMs emphasise 
the individual tonal structure that obtains in a compound involving single $\phi$-phrasing (i.e., $[. ..] \phi$ ) on one hand and one involving $\phi$-rephrasing (i.e., $\left[[. . .]_{\phi}\right] \phi$ ) on the other hand.

(20) P-structure of Akan compounds in AVM

a. ǹnùàdáń "wooden house"

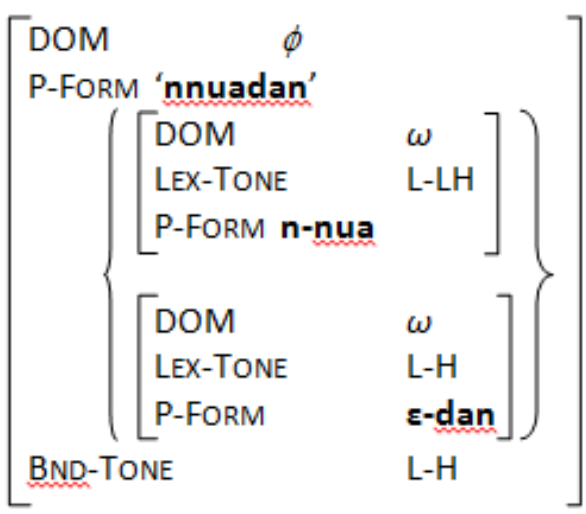

b. àkókóníní "cockerel”

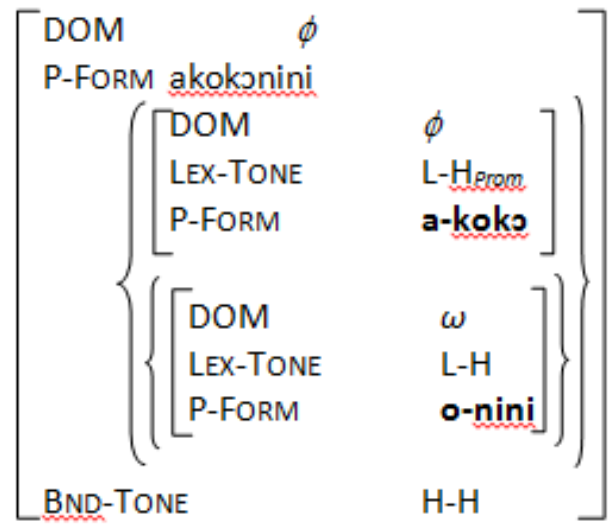

In (20a), observe that a "L-H" word boundary tone structure (BND-TONE) attains and characterises the resulting compound, which involves a single $\phi$-domain. As explained earlier and could be seen in (20a), this BND-TONE obtains from the fact that both compound members are $\omega$ s within a primary $\phi$. Accordingly, the lexical tone structure (LEX-TONE) in the stem of N1 (i.e., - LH) realises as L through the application of the H-Deletion rule, while the LEX-TONE in the stem of N2 (i.e., - $\mathrm{H}$ ) is maintained. In the case of the compound involving $\phi$-rephrasing in (20b) on the other hand, a "H-H" BND-TONE is attained. As has also been explained earlier, observe that N1 constitutes a separate $\phi$ within another $\phi$. This has been explained on the basis of tonal prominence and, with it, H-Deletion is blocked (in N1). The alternative rule of B-A is also not evident here because the prefix in N2 that should have been assimilated is elided along with its lexical $L$ tone. Both constituents in the resulting compound accordingly maintain the lexical tone structures in the stems and " $\mathrm{H}-\mathrm{H}$ " boundary tone appropriately obtains. Domain mapping in the $\mathrm{p}$-structure then explains the differences in BND-TONE between (20a) and (20b). 


\section{Conclusion}

The structure of N-N and N-Adj compounds has been explored in this paper. The desirability of the $p$-structure in the phonology-syntax interface analysis of phrasal rules in Akan compounds has been shown. It has been realised that analysis within the $p$-structure enables exhaustive explanation of phrasal rule applications. This is because, depending on other grammatical information (other than syntactic ones) available, the same syntactic structure (in this paper, NP) could be prosodised differently. Thus, the domain(s) immediately given in the syntax is inadequate or inappropriate for the explanation of phrasal rule application.

Some rules have been identified and discussed. With prosodic manipulations, where and when any one of them should apply has been established. It has been shown that the $\mathrm{H}$-Deletion rule, which has been described as essentially optional rule, is a strict $\phi$-internal rule; i.e., it applies within a primary $\phi$. Prefix elision and vocalic sequence shortening are also noted as $\phi$-internal rules. But, unlike H-Deletion, it has been observed that prefix elision and vocalic sequence shortening are not restricted in application to a primary $\phi$. Boundary assimilation (BA) has also been explained as a rule that applies across $\phi$-boundary.

Through attribute-value matrix (AVM) representation, two types of compound domains identified in this paper - i.e., single $\phi$-phrasing and $\phi$ rephrasing/recursion - and the surface tone structure each of them predicts have been presented. Having been able to explain the construction (or otherwise) of N-N and $\mathrm{N}$-Adj compounds and the application of occurring internal rules adequately with prosodic considerations, it is evident that the p-structure (and, for that matter, the prosodic hierarchy) cannot be undermined in conclusive analysis of phrasal rule applications.

\section{References}

Anderson, S. R. (1985). Typological distinction in word formation. In T. Shopen (Ed.), Language typology and syntactic description (Vol. 3). Cambridge, UK: Cambridge University Press.

Anyidoho, A. (1990). On tone in Akan compound nouns. Paper presented at the $19^{\text {th. }}$ West African Languages Congress, University of Ghana, Ghana.

Bresnan, J., \& Mchombo, S. (1995). The lexical integrity principle: Evidence from Bantu. Natural Language and Linguistics Theory, 13, 181-254.

Butt, M., \& King, T. H. (1998). Interfacing phonology with LFG. In M. Butt \& T. H. King (Eds.), Proceedings of the LFG98 Conference. Stanford: CSLI Publications; http://csli-publications.stanford.edu/LFG/3/lfg98.html

Butt, M., King, T. H., Niño, M-E, \& Segond F. (1999). A grammar writer's cookbook; CSLI lecture notes No. 95. Stanford: CSLI Publication.

Bybee, J. L. (1985). Morphology: A study of the relation between meaning and form. Amsterdam, The Netherlands: John Benjamins.

de Lacy, P. (2002). The interaction of tone and stress in Optimality Theory. Phonology, 19, 1-32. 
Dolphyne, A. F. (1988). The Akan (Twi-Fante) Language: Its sound systems and tonal structure. Accra, Ghana: Ghana University Press.

Fabb, N. (1998). Compounding. In A. Spencer \& A. M. Zwicky (Eds.), The handbook of morphology (pp. 66-83). London, UK: Blackwell Publishers.

Gamut, F. (1991). Logic, language, and meaning. Chicago, IL: University of Chicago Press.

Haspelmath, M. (2002). Understanding morphology. Hodder Headline Group, London, UK; Oxford University Press Inc.

Jackendoff, R. S. (1977). X-bar Syntax: A study of phrase structure. Cambridge, MA.: MIT Press.

Kaisse, E. M. (1985). Connected speech: The interaction of syntax and phonology. Orlando, FL: Academic Press.

Leben, W. (1973). Suprasegmental phonology. New York, NY: Garland Press.

Lieber, R. (1980). On the organisation of the lexicon. (Unpublished doctoral dissertation). Massachusetts Institute of Technology, Cambridge, Massachusetts.

Marfo, C. (2004). On tone and segmental processes in Akan phrasal words: A prosodic account. Linguistik Online, 18, 93-110.

Marfo, C. (2005). Akan focus and topic constructions and the prosody-syntax interface. Journal of West African Languages, 32(1), 45-58.

Marfo, C. (2009). Aspects of Akan grammar and the phonology-syntax interface. Saarbrucken, Germany: Lambert Academic Publishing.

Montague, R. (1974). Formal philosophy: Selected papers of Richard Montague. New Haven, CT: Yale University Press.

Odden, D. (1986). On the role of obligatory contour principle in phonological theory. Language, 62, 353-383.

Odden, D. (1987). Kimatuumbi phrasal phonology. Phonology Yearbook 4, 13-26.

Odden, D. (1990). Syntax, lexical rules and postlexical rules in Kimatuumbi. In S. Inkelas, \& D. Zec (Eds.), The Phonology-Syntax Connection (pp. 259-278). Chicago, IL: CSLI/University of Chicago Press.

Selkirk, E. O. (1984). Phonology and syntax: The relation between sound and structure. Cambridge, MA: MIT Press.

Selkirk, E. O. (1986). On derived domains in sentence phonology. Phonology Yearbook 3, 371-405.

Zec, D., \& Inkelas, S., (1990). Prosodically constrained syntax. In S. Inkelas \& D. Zec (Eds.), The phonology-syntax connection (pp. 365-378). Chicago, IL: CSLI/University of Chicago Press, Chicago. 